DOI: https://doi.org/10.47405/mjssh.v6i12.1210

\begin{tabular}{|c|c|}
\hline 4 & Malaysian Journal of Social Sciences and Humanities (MJSSH) \\
\hline 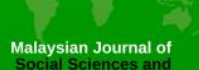 & Volume 6, Issue 12, December 2021 \\
\hline (MJ-sSH) & e-ISSN : 2504-8562 \\
\hline & $\begin{array}{l}\text { Journal home page: } \\
\text { www.msocialsciences.com }\end{array}$ \\
\hline
\end{tabular}

\title{
Sorotan Literatur Bersistematik : Faktor-Faktor Mempengaruhi Pencapaian Akademik Pelajar
}

\author{
Doreen Ting Jia Chzin'1, Shahlan Surat ${ }^{1}$ \\ 1Fakulti Pendidikan, Universiti Kebangsaan Malaysia (UKM), Malaysia \\ Correspondence: Doreen Ting Jia Chzin (p105542@siswa.ukm.edu.my)
}

\begin{abstract}
Abstrak
Pencapaian pelajar dianggap sebagai petunjuk penting dalam prestasi akademik yang cemerlang. Pencapaian akademik pelajar adalah sesuatu perkara yang dicapai pada tahap kemajuan melalui usaha dan ketekunan individu terhadap penguasaan ilmu atau kemahiran yang dipelajarinya berdasarkan kepada nilai mata yang dikumpulkannya. Pencapaian akademik yang tidak memberangsangkan menjadi buah mulut para pemimpin, tokoh-tokoh akademik dan masyarakat kerana gejala ini menyumbang kepada kadar pengangguran di Malaysia. Pelajar keluaran universiti sering diperkatakan kurang berkualiti dan tidak mempunyai daya tahan mental yang kental. Justeru, kajian ini bertujuan untuk membuat tinjauan literatur bersistematik terhadap faktor-faktor yang mempengaruhi pencapaian akademik pelajar. Kajian ini menggunakan Model Prisma. Tiga enjin carian digunakan iaitu Google Scholar, Research Gate dan Academia dan selepas proses saringan dilakukan sebanyak 17 buah artikel telah diterima berdasarkan beberapa kriteria yang ditetapkan. Dapatan menunjukkan terdapat empat faktor utama yang mempengaruhi pencapaian akademik pelajar iaitu faktor guru, faktor pelajar, faktor sekolah dan faktor sekolah. Selepas itu, sejumlah 13 sub tema yang dihasilkan oleh keempat-empat tema utama ini iaitu ciri-ciri guru, kaedah atau strategi pengajaran guru, sikap pelajar, minat pelajar, motivasi pelajar, gaya pembelajaran pelajar, kesihatan pelajar, kepimpinan guru besar atau pengetua, fasiliti-fasiliti sekolah, persekitaran sekolah, persekitaran keluarga, penglibatan ibu bapa dan latar belakang keluarga yang mempengaruhi pencapaian akademik pelajar. Beberapa cadangan yang diketengahkan mengemukakan tinjauan sistematik khusus dan standard untuk setiap tema dan tumpuan kualitatif yang menyeluruh diberikan pada kesan negatif oleh setiap faktor. Kajian ini juga bertujuan untuk mengkaji lebih lanjut mengenai pengaruh faktor jantina terhadap pencapaian akademik pelajar.
\end{abstract}

Kata kunci: faktor-faktor, pencapaian akademik, sorotan literatur bersistematik

\section{Systematic Literature Review: Factors Influencing Students' Academic Achievement}

\begin{abstract}
Student achievement is considered an important indicator of outstanding academic performance. The academic achievement of a student is something that is achieved at the level of progress through the efforts and diligence of the individual towards the mastery of knowledge or skills that student has learned based on the value of the points student has accumulated. Unsatisfactory academic achievements have become the talk of leaders, academic figures and the community as these symptoms contribute to the unemployment rate in Malaysia. University graduates are often said to be of poor quality and lack strong mental resilience. Thus, this study aims to make a systematic literature review
\end{abstract}


of the factors that influence student academic achievement. This study uses the PRISMA model. Article search may include three main databases of Google Scholar, Research Gate and Academia and after the screening process, a total of 17 articles were received based on several criteria. The findings show that there are four main factors that influence students' academic achievement, namely teacher factors, student factors, school factors and family factors. After that, a total of 13 sub-themes produced by these four main themes namely teachers' characteristics, teachers' teaching methods or strategies, students' attitudes, students' interests, students' motivation, students' learning styles, students' health, leadership of headmaster or principal, school facilities, school environment, family environment, parental involvement and family background that influence students' academic achievement. Some of the recommendations presented present a specific systematic review and standards for each theme and a comprehensive qualitative focus is given on the negative effects of each factor. This study also aims to examine further on the influence of gender factors on students 'academic achievement.

Keywords: factors, academic achievement, systematic review

\section{Pengenalan}

Pendidikan memainkan peranan yang sangat penting di mana-mana negara untuk pembangunan modal insan dan pendidikan merupakan tunjang utama dalam merealisasikan misi sesebuah negara. Demi mencapai misi yang ditetapkan, kerajaan telah mengambil perhatian yang serius dengan mewujudkan sistem pendidikan yang menawarkan pembelajaran kepada pelbagai lapisan masyarakat dan peringkat umur. Kaedah pembelajaran yang seimbang mampu melahirkan masyarakat yang berkualiti dan menyumbang ke arah pertumbuhan negara.

Bagi masyarakat Malaysia, elemen kualiti pendidikan ialah pengurusan dan pentadbiran yang seimbang dan mengamalkan budaya pendidikan yang cemerlang dari semua aspek kehidupan. Dalam Falsafah Pendidikan Negara menyatakan pendidikan juga berteraskan kepercayaan dan kepatuhan kepada Tuhan, bersatu padu, bertanggungjawab, beramanah, bermotivasi dan keazaman untuk mencapai kesejahteraan diri serta bercita-cita ke arah kemakmuran masyarakat dan negara.

Menurut Muhammad Shafiq dan Noraini (2018), kerajaan terus membiayai institusi pendidikan dengan meletakkan kepercayaan yang tinggi bahawa pendidikan itu ialah alat untuk membawa kemajuan yang sejajar dengan kehendak dan aspirasi sesuatu masyarakat mengikut perkembangan semasa. Sekolah pula menyediakan prasarana dan peluang untuk merealisasikan hasrat tersebut melalui proses pendidikan. Guru pula menyediakan suasana bilik darjah yang kondusif untuk individu pelajar berkembang. Manakala ibu bapa mempunyai aspirasi tersendiri terhadap perkembangan anak-anak mereka dari segi akademik, sosial dan emosi termasuk aspek konsep kendiri dan motivasi pencapaian. Justeru itu dalam proses pendidikan, keempat-empat komponen di atas perlu bekerjasama dan saling bantu membantu untuk melahirkan individu yang seimbang.

Pencapaian akademik pelajar adalah sesuatu perkara yang dicapai pada tahap kemajuan melalui usaha dan ketekunan individu terhadap penguasaan ilmu atau kemahiran yang dipelajarinya berdasarkan kepada nilai mata yang dikumpulkannya (Hafizah, 2015). Pencapaian ini diukur berdasarkan gred, skor mentah, dan pangkat untuk subjek atau keseluruhan kursus (Hafizah, 2015). Dengan erti kata lain, pencapaian merupakan kayu ukur kejayaan atau kegagalan pelajar berasaskan penilaian dan peperiksaan dalam sesuatu ujian. Gred bacaan baik yang diperolehi daripada instrumen penilaian pelajar dapat menghasilkan kesesuaian gaya pembelajaran serta memperolehi kecemerlangan dalam keputusan pencapaian pelajar.

Menurut Halimatus (2020), kecemerlangan akademik adalah segala aktiviti yang dilakukan bagi menentukan kejayaan tercapai pada tahap maksimum. Dalam hal ini secara lazimnya menjadi cita-cita bagi seorang pelajar ketika membuat permohonan meneruskan pengajian ke peringkat seterusnya. Namun, pencapaian akademik yang tidak memberangsangkan menjadi buah mulut para pemimpin, tokoh-tokoh akademik dan masyarakat kerana gejala ini menyumbang kepada kadar pengangguran di 
Malaysia. Pelajar keluaran universiti sering diperkatakan kurang berkualiti dan tidak mempunyai daya tahan mental yang kental (Norasmah, 2017). Masalah disiplin dan sikap pelajar, keluarga dan persekitaran sekolah merupakan permasalahan yang paling dominan mempengaruhi pencapaian akademik dalam kalangan pelajar (Mohd. Erfy, 2019). Pencapaian akademik pelajar sering dilihat dari sudut kebolehan yang terdapat pada pelajar itu. Namun tidak boleh dinafikan bahawa, terdapat faktorfaktor lain yang boleh mempengaruhi pencapaian akademik pelajar iaitu persekitaran tempat belajar, gaya keibubapaan, gaya pembelajaran dan lain-lain (Muhamad Shafiq \& Norani, 2018).

Menurut Mohamad Rofian et al. (2020), terdapat dua faktor utama yang mempengaruhi kecemerlangan akademik pelajar iaitu faktor luaran dan faktor dalaman. Faktor luaran merupakan desakan dan elemen luar yang mendorong dan membantu pelajar untuk berjaya dalam akademik manakala faktor dalaman adalah merupakan sikap dan usaha pelajar itu sendiri untuk berjaya dalam akademik. Namun begitu, kecemerlangan pelajar banyak juga bergantung kepada pelbagai faktor. Faktor kejayaan pelajar tidak sahaja bergantung kepada faktor diri sendiri atau faktor dalaman tetapi juga faktor luaran. Hal ini kerana kejayaan pelajar bukan sahaja bergantung kepada dirinya sahaja tetapi juga sistem pendidikan, guruguru, kemudahan di sekolah, ibu bapa dan persekitaran keluarga. Objektif utama kajian ini adalah untuk mengkaji faktor-faktor yang mempengaruhi pencapaian akademik pelajar

\section{Sorotan Literatur}

Terdapat banyak kajian yang dilakukan terhadap faktor-faktor yang mempengaruhi prestasi akademik pelajar pada tahap pengajian yang berbeza. Dhakal (2020) meneroka faktor sekolah, faktor pelajar dan faktor ibu bapa yang mempengaruhi prestasi akademik pelajar. Namun, Atchia dan Chinapah (2019) telah menganalisis faktor sosioekonomi keluarga, kepemimpinan sekolah, faktor pelajar dan faktor guru yang mempengaruhi pencapaian akademik pelajar sekolah menengah di Mauritius. Mereka mendapati semua faktor tersebut memberi kesan positif terhadap pencapaian akademik pelajar. Mushtaq dan Khan (2012) mendapati komunikasi, kemudahan pembelajaran, bimbingan guru yang betul dan baik mempunyai hubungan positif yang signifikan dengan prestasi akademik pelajar. Kajian Mahato (2018) menunjukkan bahawa aktiviti kurikulum, pengurusan sekolah, proses pembelajaran dan faktor fasiliti institusi pendidikan menyumbang kepada prestasi akademik pelajar.

Selain itu, terdapat pelbagai kajian yang menyatakan faktor-faktor yang menyumbang kepada pencapaian akademik pelajar adalah berpunca daripada kaedah pembelajaran, pendekatan pengajaran guru serta sikap pelajar sendiri (Muhamad Shafiq \& Noraini, 2018). Terdapat peningkatan dalam penglibatan pendidik dalam mengenal pasti faktor-faktor yang mempengaruhi pencapaian akademik pelajar. Beberapa kajian diberi tumpuan semasa mengkaji faktor pelajar, sekolah dan keluarga dalam mempengaruhi pencapaian akademik pelajar. Dari aspek faktor pelajar, pencapaian akademik dipengaruhi secara signifikan oleh sifat pelajar seperti minat, motivasi, dan sikap pelajar (Aydeniz \& Kaya, 2015). Selain itu, ada pelajar yang memasuki kelas dengan persepsi buruk mereka, jangkaan yang rendah terhadap subjek tersebut dan keupayaan mereka untuk berjaya. Oleh itu, ia dapat ditunjukkan dari persepsi pelajar bahawa mereka tidak yakin dengan kebolehan mereka dan ini akan mempengaruhi pencapaian mereka dalam akademik (Aydeniz \& Kaya, 2015).

Dari segi faktor keluarga, bantuan dan sokongan ibu bapa yang tidak mencukupi di kalangan pelajar Somalia di United Kingdom menyebabkan keputusan akademik mereka rendah (Demie, Lewis \& Mclean, 2007). Faktor yang mempengaruhi keputusan akademik tersebut juga merangkumi latar belakang sosio-ekonomi, kemahiran, sikap, cita-cita dan pembelajaran sebelumnya. Dari aspek faktor sekolah, didapati bahawa faktor sekolah yang berkaitan dengan pencapaian akademik pelajar adalah faktor yang terutama berkaitan dengan konteks sekolah, ciri dan sumber sekolah dan ciri bilik darjah (Mullis et al., 2012). Arahan berkait rapat dengan ciri bilik darjah. Mereka juga menunjukkan bahawa arahan yang tepat yang disampaikan oleh guru akan meningkatkan pemahaman konsep pelajar dan proses pembelajaran pelajar akan meningkat melalui pendedahan kepada strategi pengajaran yang ketat yang dilaksanakan di dalam kelas. Dengan itu, jelaslah bahawa faktor guru memainkan peranan penting seperti pengalaman dan sikap guru dalam bilik darjah akan mempengaruhi persekitaran pembelajaran 
mereka dan akan memberi kesan kepada pencapaian mereka (Riska Yurnaliza \& Totoh Andayono, 2019).

\section{Metod Kajian}

Kajian literatur bersistematik ini menggunakan garis panduan PRISMA seperti yang ditunjukkan dalam Rajah 1. Model PRISMA memberi panduan kepada penulis untuk membuat kajian literatur bersistematik berasaskan bukti-bukti yang dikumpulkan oleh penulis. Nilai kajian literatur bersistematik ini bergantung kepada pelaksanaan ulasan, dapatan kajian dan laporan yang jelas. Terdapat empat peringkat dalam menghasilkan sorotan literatur bersistematik iaitu mengenal pasti, menyaring, memeriksa kelayakan, dan merangkum.

\section{Rajah 1: Model PRISMA}
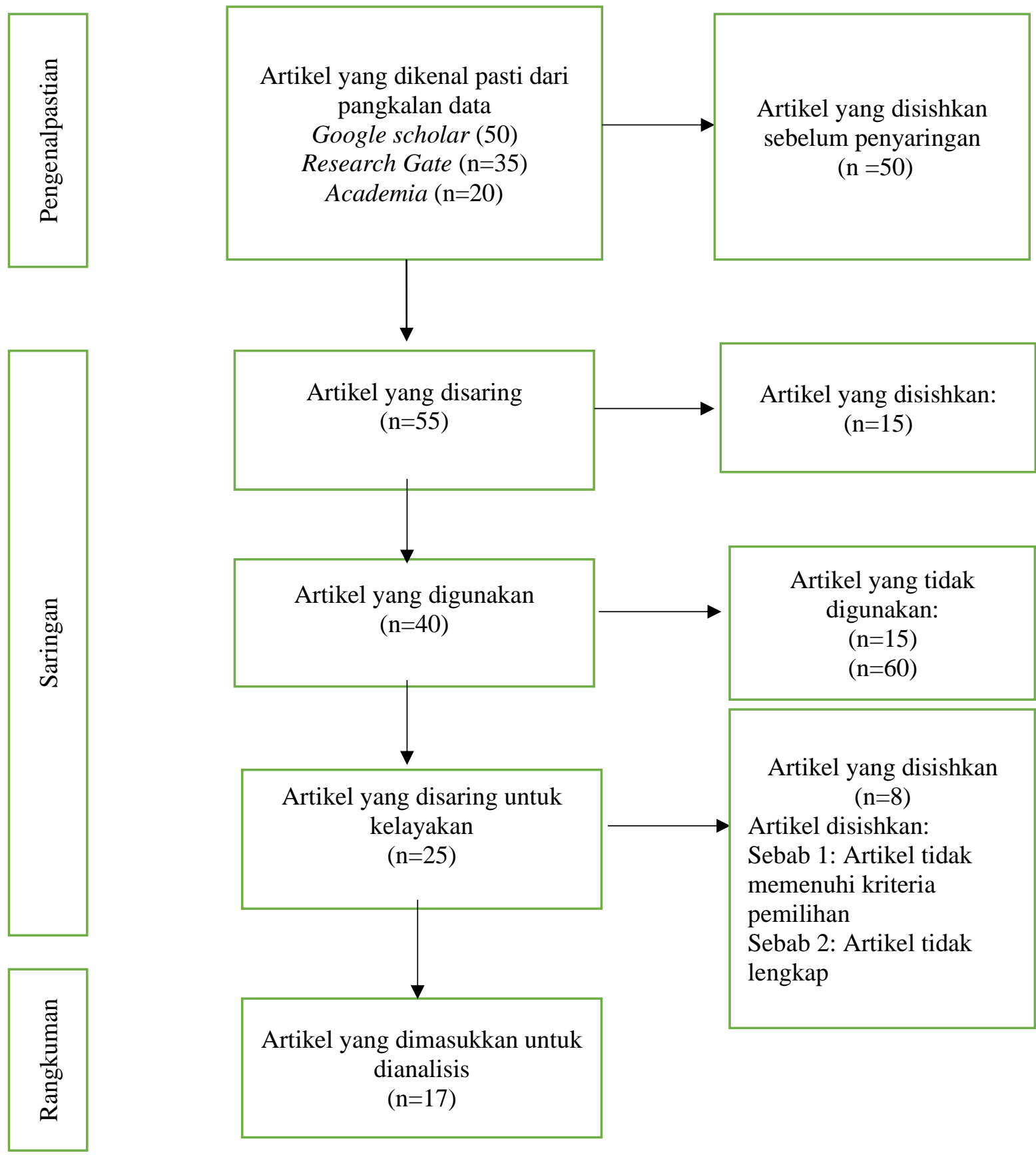

$$
\begin{gathered}
\text { dianalisis } \\
(n=17)
\end{gathered}
$$




\section{Peringkat Pengenalpastian}

Pangkalan data yang digunakan untuk mencari artikel berkaitan dengan kajian ini adalah Google scholar, Research Gate and Academia. Pangkalan data dipilih memandangkan ianya mengumpulkan penerbitan ilmiah dalam kajian faktor-faktor mempengaruhi pencapaian akademik pelajar. Pencarian artikel di pangkalan data telah menggunakan beberapa kata istilah carian berikut gabungan dalam Bahasa Inggeris mengenai "factor influence" atau "factor impact" atau "factor cause" dan "students' academic achievement". Kata kunci dalam Bahasa Melayu juga turut digunakan seperti "faktor" dan "prestasi pelajar" atau "pencapaian akademik" bagi mencari artikel yang menggunakan Bahasa Melayu dalam penulisan laporan artikel.

\section{Peringkat Penyaringan}

Terdapat beberapa kriteria pencarian penulisan artikel telah ditetapkan sebelum memulakan proses pencarian. Pertamanya, sumber artikel dihadkan dalam tempoh lima tahun penerbitan terkini iaitu dari Januari 2017 hingga 2021. Tujuannya untuk mendapatkan maklumat yang terkini tentang faktor-faktor mempengaruhi pencapaian akademik pelajar. Kajian literatur bersistematik ini hanya memfokuskan kajian empirikal sahaja kerana kajian empirikal mempunyai dapatan kajian yang utuh dan terbukti melalui penyelidikan serta telah mempunyai kesahan dan kebolehpercayaan yang tinggi. Selain itu, kriteria pemilihan artikel terpilih juga termasuk hanya melibatkan artikel akses terbuka. Tujuan ini untuk memudahkan proses perolehan dan muat turun artikel. Tambahan pula, pencarian ini berfokus faktor-faktor yang mempengaruhi pencapaian akademik pelajar. Tinjauan awalan dijalankan dengan berdasarkan tajuk artikel, abstrak dan kata kunci. Teks penuh dicari dan dibaca untuk artikel yang memenuhi kriteria kelayakan berdasarkan tajuk dan abstrak dan menentukan sama ada artikel ini akan dikekalkan atau dikecualikan dalam pencarian terakhir atau tidak. Manakala bagi penolakan kriteria sumber artikel termasuk penulisan penyelidikan yang lain seperti buku, laporan atau prosiding yang tidak diterbitkan tidak termasuk dalam pemilihan ini. Penulisan sumber-sumber ilmiah ini tidak dipilih kerana objektif dan kredibiliti mereka yang harus diambil kira sebagai mereka tidak melalui proses tinjauan rakan sebaya (Liyanagunawardena et al., 2013). Di samping itu, sumber penulisan kajian juga hanya memilih artikel yang ditulis dalam Bahasa Melayu, Inggeris dan Indonesia yang telah diterjemahkan ke dalam Bahasa Melayu.

\section{Peringkat Rangkuman}

Peringkat terakhir adalah peringkat rangkuman di mana penyelidik melihat setelah semua artikel disaring, terdapat 17 artikel penuh yang layak. Oleh hal yang demikian, peringkat ini secara tidak langsung dapat menunjukkan berapa artikel yang betul-betul layak mengikut saringan aspek yang telah ditetapkan.

\section{Hasil Kajian}

Jadual 2 menunjukkan rumusan maklumat yang dianalisis dari 17 artikel. Rumusan artikel adalah berkaitan dengan faktor-faktor yang mempengaruhi pencapaian akademik pelajar. Rumusan artikel kepada 6 bahagian yang terdiri daripada tajuk, pengarang dan tahun penerbitan, negara, metodologi, kaedah pengumpulan data dan dapatan kajian. 
Jadual 2: Rumusan analisis tajuk, pengarang dan tahun penerbitan, negara, reka bentuk kajian, pengumpulan data dan dapatan kajian

\begin{tabular}{|c|c|c|c|c|c|}
\hline Tajuk & $\begin{array}{l}\text { Pengarang/Tahun } \\
\text { Terbitan }\end{array}$ & Negara & Metodologi & $\begin{array}{l}\text { Kaedah } \\
\text { pengumpulan } \\
\text { data }\end{array}$ & Dapatan Kajian \\
\hline $\begin{array}{l}\text { Factors } \\
\text { Affecting } \\
\text { Students' } \\
\text { Academic } \\
\text { Achievement in } \\
\text { Zimbabwe's } \\
\text { Rural } \\
\text { Secondary } \\
\text { Schools: A Case } \\
\text { Study of } \\
\text { Marimasimbe } \\
\text { Secondary } \\
\text { School in Jiri } \\
\text { Community } \\
\end{array}$ & $\begin{array}{l}\text { Munyaradzi } \\
\text { Nyoni, Thabani } \\
\text { Nyoni \& } \\
\text { Wellington G. } \\
\text { Bonga (2017) }\end{array}$ & Zimbabwe & $\begin{array}{l}\text { Reka bentuk } \\
\text { kajian : } \\
\text { Kualitatif }\end{array}$ & $\begin{array}{l}\text { Instrumen : } \\
\text { Pemerhatian, } \\
\text { soal selidik, } \\
\text { temu bual } \\
\text { kumpulan } \\
\text { fokus dan } \\
\text { semakan } \\
\text { dokumen }\end{array}$ & $\begin{array}{l}\text { Hasil kajian menunjukkan bahawa jenis kepemimpinan sekolah } \\
\text { oleh pengetua sekolah, bimbingan kerjaya, guru yang } \\
\text { berkelayakan, berdisiplin dan berdedikasi sebagai adalah faktor } \\
\text { dalaman utama yang mempengaruhi pencapaian akademik pelajar. } \\
\text { Faktor luaran yang dikenal pasti adalah status sosioekonomi } \\
\text { keluarga, hubungan sekolah-komuniti dan jarak ke sekolah. } \\
\text { Pengkaji mengesyorkan mewujudkan persekitaran sekolah yang } \\
\text { kondusif oleh ketua sekolah, dengan mengambil bimbingan kerjaya } \\
\text { lebih serius lagi, pengambilan guru berkelayakan yang mencukupi } \\
\text { dan berdedikasi untuk pekerjaan mereka, mengekalkan disiplin dan } \\
\text { ketertiban oleh kedua ibu bapa dan guru. }\end{array}$ \\
\hline $\begin{array}{l}\text { Mengenalpasti } \\
\text { faktor-faktor } \\
\text { yang } \\
\text { mempengaruhi } \\
\text { pencapaian } \\
\text { akademik } \\
\text { pelajar Sarjana } \\
\text { Muda } \\
\text { Psikologi, Kolej } \\
\text { Universiti Islam } \\
\text { Melaka } \\
\text { (KUIM) }\end{array}$ & $\begin{array}{l}\text { Muhamad Shafiq } \\
\text { \& Noraini (2018) }\end{array}$ & Malaysia & $\begin{array}{l}\text { Reka bentuk } \\
\text { kajian : } \\
\text { Kajian } \\
\text { berbentuk } \\
\text { kuantitatif } \\
\text { yang } \\
\text { menggunakan } \\
\text { reka bentuk } \\
\text { tinjauan } \\
\text { (survey). }\end{array}$ & $\begin{array}{l}\text { Instrumen : } \\
\text { Soal selidik. }\end{array}$ & $\begin{array}{l}\text { Terdapat hubungan yang signifikan antara sikap, minat dan kaedah } \\
\text { pembelajaran dengan pencapaian akademik pelajar. } \\
\text { Bagi faktor pensyarah pula, didapati tidak terdapat hubungan yang } \\
\text { signifikan dengan pencapaian akademik pelajar. }\end{array}$ \\
\hline
\end{tabular}




\begin{tabular}{|c|c|c|c|c|c|}
\hline $\begin{array}{l}\text { Pencapaian Pelajar } \\
\text { dalam Mata } \\
\text { Pelajaran Geografi } \\
\text { Sekolah Menengah } \\
\text { di Sabah }\end{array}$ & $\begin{array}{l}\text { Hanifah Mahat et } \\
\text { al. (2017) }\end{array}$ & Malaysia & $\begin{array}{l}\text { Reka bentuk: } \\
\text { Kajian } \\
\text { tinjauan }\end{array}$ & $\begin{array}{l}\text { Instrumen: } \\
\text { Soal selidik }\end{array}$ & $\begin{array}{l}\text { Dapatan kajian menunjukkan sikap mempunyai hubungan yang } \\
\text { signifikan dengan pencapaian. Manakala minat, peranan guru dan } \\
\text { peranan ibu bapa tidak mempunyai hubungan yang signifikan } \\
\text { dengan pencapaian pelajar. } \\
\text { Dapatan kajian ini memberi implikasi kepada pelaksanaan mata } \\
\text { pelajaran geografi di sekolah jangka masa panjang. }\end{array}$ \\
\hline $\begin{array}{l}\text { Faktor-faktor } \\
\text { Determinan Yang } \\
\text { Mempengaruhi } \\
\text { Prestasi Belajar } \\
\text { Siswa }\end{array}$ & $\begin{array}{l}\text { Tohol Simamora, } \\
\text { Edi Harapan \& } \\
\text { Nila Kesumawati } \\
(2020)\end{array}$ & Indonesia & $\begin{array}{l}\text { Reka bentuk: } \\
\text { Kaedah } \\
\text { Tinjauan } \\
\text { (Kuantitatif) }\end{array}$ & $\begin{array}{l}\text { Instrumen : } \\
\text { Soal selidik } \\
\text { dan } \\
\text { dokumentasi }\end{array}$ & $\begin{array}{l}\text { Terdapat pengaruh motivasi belajar terhadap pencapaian } \\
\text { pembelajaran. } \\
\text { Ada pengaruh minat belajar terhadap pencapaian pembelajaran. } \\
\text { Tidak ada pengaruh keadaan ekonomi keluarga terhadap } \\
\text { pembelajaran pencapaian. } \\
\text { Terdapat pengaruh tahap pendidikan ibu bapa terhadap pencapaian } \\
\text { pembelajaran. } \\
\text { Terdapat pengaruh motivasi belajar, minat belajar, keadaan } \\
\text { ekonomi keluarga, tahap pendidikan ibu bapa terhadap pencapaian } \\
\text { pembelajaran. }\end{array}$ \\
\hline $\begin{array}{l}\text { Pengaruh Latar } \\
\text { Belakang Keluarga } \\
\text { Dan Pencapaian } \\
\text { Akademik Pelajar } \\
\text { Di SMK Bau }\end{array}$ & $\begin{array}{l}\text { Melvin \& Shahlan } \\
\text { Surat (2020) }\end{array}$ & Malaysia & $\begin{array}{l}\text { Reka bentuk : } \\
\text { Deskriptif } \\
\text { Kuantitatif }\end{array}$ & $\begin{array}{l}\text { Instrumen : } \\
\text { Soal selidik }\end{array}$ & $\begin{array}{l}\text { Kajian ini mendapati terdapat hubungan signifikan yang lemah } \\
\text { dengan ketiga - tiga pemboleh ubah tak bersandar iaitu pendidikan, } \\
\text { pekerjaan dan pendapatan ibu bapa. } \\
\text { Pendidikan ibu dan bapa, pekerjaan bapa dan pendapatan ibu bapa } \\
\text { hanya memberi pengaruh yang kecil manakala pekerjaan ibu dan } \\
\text { pendapatan ibu menunjukkan tiada kesignifikan terhadap } \\
\text { pencapaian akademik pelajar tingkatan } 1 \text { dan } 4 \text { di SMK Bau. }\end{array}$ \\
\hline $\begin{array}{l}\text { Faktor-faktor yang } \\
\text { mempengaruhi } \\
\text { pencapaian } \\
\text { akademik } \\
\text { Mahasiswa } \\
\text { Bidikmisi Fakultas } \\
\text { Teknik Universitas } \\
\text { Negeri Padang }\end{array}$ & $\begin{array}{l}\text { Riska Yurnaliza \& } \\
\text { Totoh Andayono, } \\
\text { ST.(2019) }\end{array}$ & Indonesia & $\begin{array}{l}\text { Reka bentuk : } \\
\text { Deskriptif } \\
\text { Kuantitatif }\end{array}$ & $\begin{array}{l}\text { Instrumen : } \\
\text { Soal Selidik }\end{array}$ & $\begin{array}{l}\text { Hasil kajian menunjukkan faktor yang paling mempengaruhi } \\
\text { pencapaian akademik pelajar Bidikmisi FT UNP dari faktor luaran, } \\
\text { iaitu keluarga dengan skor pencapaian skor tertinggi adalah } 85.81 \% \\
\text { manakala skor terendah adalah } 64.21 \% \text { dari faktor persekitaran. Hal } \\
\text { ini menunjukkan bahawa persekitaran keluarga cukup } \\
\text { memberangsangkan sehingga pelajar mendapat pencapaian } \\
\text { akademik yang baik. }\end{array}$ \\
\hline
\end{tabular}




\begin{tabular}{|c|c|c|c|c|c|}
\hline $\begin{array}{l}\text { Factors that } \\
\text { Influence } \\
\text { Student } \\
\text { Learning } \\
\text { Achievement }\end{array}$ & $\begin{array}{l}\text { Lastri, Sri } \\
\text { Kartikowati, } \\
\text { Sumarno (2020) }\end{array}$ & Indonesia & $\begin{array}{l}\text { Reka bentuk: } \\
\text { Deksriptif } \\
\text { Kuantitatif }\end{array}$ & $\begin{array}{l}\text { Instrumen : } \\
\text { Soal selidik } \\
\text { dan } \\
\text { Dokumentasi }\end{array}$ & $\begin{array}{l}\text { Hasil kajian menunjukkan bahawa motivasi belajar mempunyai pengaruh } \\
\text { positif dan signifikan terhadap pencapaian pembelajaran. } \\
\text { Minat belajar mempunyai kesan positif dan signifikan terhadap } \\
\text { pencapaian pembelajaran. } \\
\text { Persekitaran keluarga mempunyai kesan positif dan signifikan terhadap } \\
\text { pencapaian pembelajaran, dan motivasi belajar juga memberi kesan } \\
\text { positif dan signifikan terhadap pencapaian pembelajaran. } \\
\text { Terdapat pengaruh antara motivasi belajar, minat belajar, persekitaran } \\
\text { keluarga dan model pembelajaran, dengan pencapaian pembelajaran. }\end{array}$ \\
\hline $\begin{array}{l}\text { Factors that } \\
\text { Influence } \\
\text { Students' } \\
\text { Learning : An } \\
\text { Observation on } \\
\text { Vocational } \\
\text { College } \\
\text { Students. }\end{array}$ & $\begin{array}{l}\text { Mohd Erfy Ismail } \\
\text { et al. (2019) }\end{array}$ & Malaysia & $\begin{array}{l}\text { Reka bentuk: } \\
\text { Kajian } \\
\text { tinjauan } \\
\text { (kuantitaif) }\end{array}$ & $\begin{array}{l}\text { Instrumen : } \\
\text { Soal selidik }\end{array}$ & $\begin{array}{l}\text { Hasil kajian menunjukkan bahawa terdapat hubungan yang signifikan di } \\
\text { antara pencapaian pelajar dan minat pelajar, penglibatan ibu bapa dan } \\
\text { pengajaran guru. } \\
\text { Untuk faktor minat pelajar, pelajar yang mempunyai pencapaian yang } \\
\text { baik dalam beberapa mata pelajaran adalah mereka yang mempunyai } \\
\text { minat terhadap subjek tersebut. } \\
\text { Penglibatan ibu bapa dalam tugas pelajar di rumah akan membantu } \\
\text { mereka meningkatkan pencapaian mereka di sekolah. } \\
\text { Seterusnya, dalam proses pengajaran, guru mesti menimbulkan minat } \\
\text { belajar pelajar, membimbing mereka dalam cara pembelajaran yang } \\
\text { berkesan, menyediakan bahan pengajaran dan meningkatkan kemahiran } \\
\text { penguasaan mereka. }\end{array}$ \\
\hline $\begin{array}{l}\text { Faktor-faktor } \\
\text { Yang } \\
\text { Mempengaruhi } \\
\text { Pencapaian } \\
\text { Akademik } \\
\text { Pelajar } \\
\text { Politeknik } \\
\text { METrO Betong } \\
\text { Sarawak }\end{array}$ & $\begin{array}{l}\text { Halimatus Saadiah } \\
\text { Kariya }(2020)\end{array}$ & Malaysia & $\begin{array}{l}\text { Reka Bentuk: } \\
\text { Kuantitatif }\end{array}$ & $\begin{array}{l}\text { Instrumen: } \\
\text { Soal Selidik }\end{array}$ & $\begin{array}{l}\text { Hasil kajian menunjukkan faktor daripada pengajaran dan pembelajaran } \\
\text { pensyarah merupakan faktor yang paling tinggi diikuti faktor minat } \\
\text { pelajar dan faktor sikap pelajar. } \\
\text { Justeru, melalui kajian ini kesemua faktor menunjukkan hubungan yang } \\
\text { signifikan dalam mempengaruhi pencapaian akademik pelajar. }\end{array}$ \\
\hline
\end{tabular}




\begin{tabular}{|c|c|c|c|c|c|}
\hline $\begin{array}{l}\text { Faktor-faktor } \\
\text { Yang } \\
\text { Mempengaruhi } \\
\text { Prestasi } \\
\text { Akademik Siswa } \\
\text { Sekolah Dasar }\end{array}$ & $\begin{array}{l}\text { Azza Salsabila \& } \\
\text { Puspitasari (2020) }\end{array}$ & Indonesia & $\begin{array}{l}\text { Reka bentuk: } \\
\text { Deskriptif }\end{array}$ & $\begin{array}{l}\text { Instrumen : } \\
\text { Pemerhatian, } \\
\text { temu bual, } \\
\text { dokumentasi }\end{array}$ & $\begin{array}{l}\text { Hasil kajian ini di SDN KUTAJAYA II menunjukkan bahawa faktor- } \\
\text { faktor yang mempengaruhi pencapaian pembelajaran pada pelajar } \\
\text { kelas IV dipengaruhi oleh faktor dalaman dan faktor luaran. } \\
\text { Faktor dalaman merangkumi faktor fizikal dan faktor psikologi. } \\
\text { Faktor fizikal seperti keadaan kesihatan, keadaan badan dan faktor } \\
\text { psikologi seperti perhatian, minat, bakat, dan kesediaan. } \\
\text { Manakala faktor luaran, iaitu faktor sekolah seperti kurikulum, kaedah } \\
\text { pengajaran, interaksi antara pelajar, disiplin di sekolah, alat } \\
\text { pembelajaran, keadaan bangunan, dan perpustakaan, dan hasil } \\
\text { pencapaian pembelajaran di SDN KUTAJAYA II berada dalam } \\
\text { kriteria yang baik. }\end{array}$ \\
\hline $\begin{array}{l}\text { Effects of } \\
\text { Physical } \\
\text { Facilities at } \\
\text { Public Schools } \\
\text { on Students' } \\
\text { Achievement in } \\
\text { Punjab, } \\
\text { Pakistan }\end{array}$ & $\begin{array}{l}\text { Muhammad } \\
\text { Arshad, Zia Ahmad } \\
\text { Qamar \& Faheem } \\
\text { Huma Gulzar } \\
\text { (2018) }\end{array}$ & Pakistan & $\begin{array}{l}\text { Reka Bentuk: } \\
\text { Kajian } \\
\text { bersifat } \\
\text { kuantitatif } \\
\text { dengan } \\
\text { menggunakan } \\
\text { kaedah } \\
\text { tinjauan }\end{array}$ & $\begin{array}{l}\text { Instrumen : } \\
\text { Soal selidik }\end{array}$ & $\begin{array}{l}\text { Kajian menunjukkan bahawa pengudaraan, tanaman, taman } \\
\text { permainan, kotak perubatan pertolongan cemas, LCD / LED sangat } \\
\text { mempengaruhi pencapaian akademik pelajar. Semua kemudahan } \\
\text { fizikal menyumbang sekitar } 15.4 \% \text { terhadap pencapaian akademik } \\
\text { pelajar. }\end{array}$ \\
\hline $\begin{array}{l}\text { Factors } \\
\text { influence the } \\
\text { digital media } \\
\text { teaching of } \\
\text { primary school } \\
\text { teachers in a } \\
\text { flipped class: A } \\
\text { Taiwan case } \\
\text { study }\end{array}$ & $\begin{array}{l}\text { Yung-hsun Cheng } \\
\text { \& Chia-wen Weng } \\
\text { (2017) }\end{array}$ & Taiwan & $\begin{array}{l}\text { Reka benuk: } \\
\text { Kajian } \\
\text { bersifat } \\
\text { kuantitatif } \\
\text { dengan } \\
\text { menggunakan } \\
\text { kaedah } \\
\text { tinjauan. }\end{array}$ & $\begin{array}{l}\text { Instrumen : } \\
\text { Soal selidik }\end{array}$ & $\begin{array}{l}\text { Hasil kajian adalah seperti berikut: } \\
\text { (1) kepemimpinan guru besar mempunyai kesan positif terhadap } \\
\text { pencapaian pembelajaran pelajar; } \\
\text { (2) kepemimpinan guru besar mempunyai pengaruh positif terhadap } \\
\text { sikap guru dalam pengajaran media digital; } \\
\text { (3) sikap guru menggunakan media digital memberi kesan positif } \\
\text { terhadap pencapaian pembelajaran pelajar; } \\
\text { (4) sikap guru terhadap pengajaran media digital menyederhanakan } \\
\text { hubungan antara kepemimpinan guru besar dengan pencapaian } \\
\text { pembelajaran pelajar; dan (5) penglibatan ibu bapa memberi kesan } \\
\text { positif terhadap pencapaian pembelajaran pelajar. }\end{array}$ \\
\hline
\end{tabular}




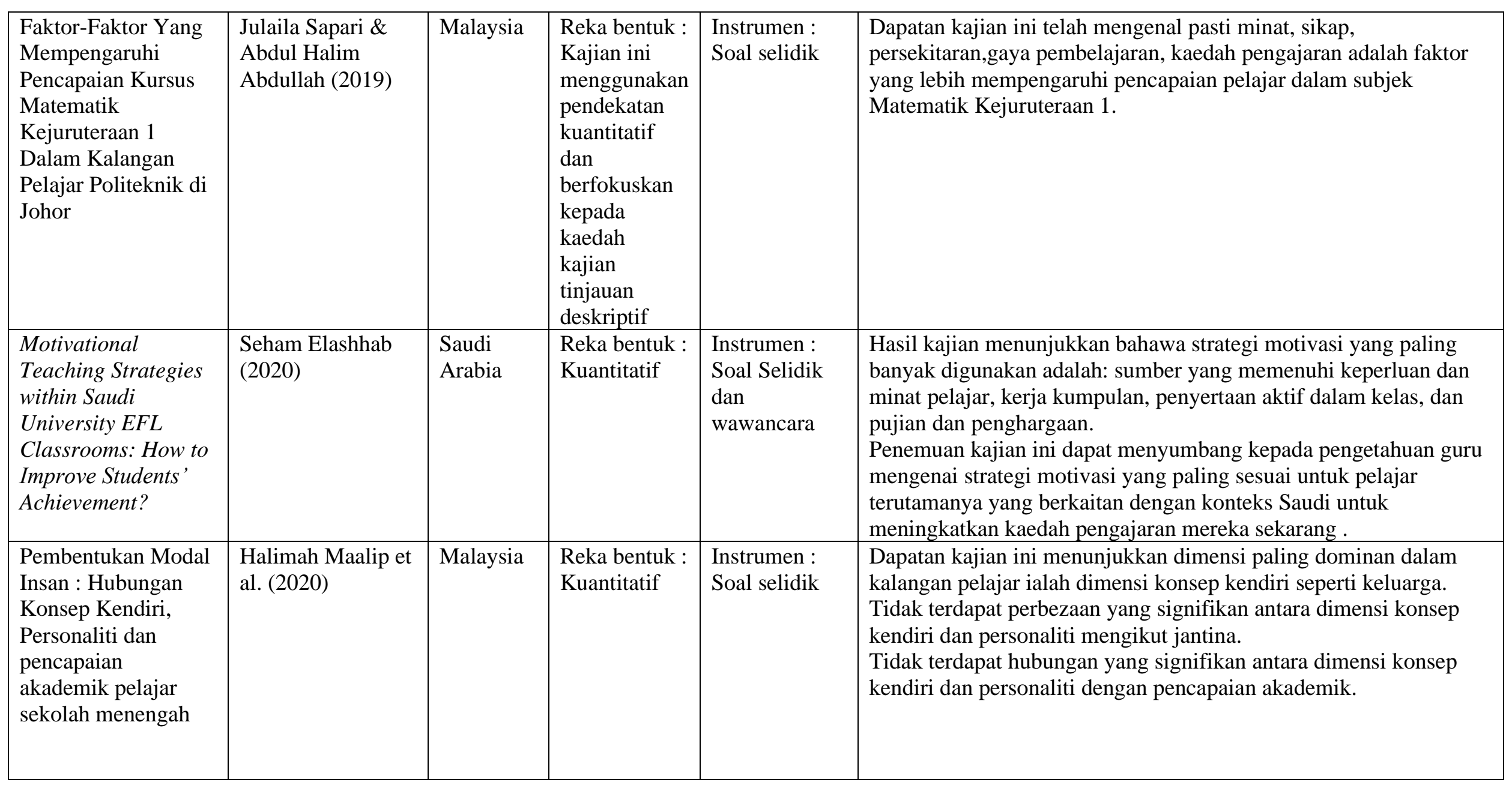




\begin{tabular}{|c|c|c|c|c|c|}
\hline $\begin{array}{l}\text { Factors } \\
\text { Affecting } \\
\text { Students' } \\
\text { Academic } \\
\text { Performance: } \\
\text { The Case of } \\
\text { Students at } \\
\text { Community } \\
\text { Colleges in } \\
\text { Bhaktapur } \\
\text { District }\end{array}$ & $\begin{array}{l}\text { Balaram Duwal \& } \\
\text { Lalita Khonju } \\
\text { (2020) }\end{array}$ & Nepal & $\begin{array}{l}\text { Reka bentuk: } \\
\text { Kaedah } \\
\text { tinjauan }\end{array}$ & $\begin{array}{l}\text { Instrumen : } \\
\text { Soal selidik }\end{array}$ & $\begin{array}{l}\text { Hasil kajian menunjukkan bahawa kaedah pengajaran dan kehadiran } \\
\text { pelajar mempunyai kesan positif yang signifikan terhadap prestasi } \\
\text { pelajar tetapi tabiat pelajar tidak mempunyai kesan yang signifikan } \\
\text { terhadap prestasi pelajar. }\end{array}$ \\
\hline $\begin{array}{l}\text { Investigation } \\
\text { into Factors } \\
\text { Affecting } \\
\text { Students, } \\
\text { Academic } \\
\text { Performance in } \\
\text { Tertiary } \\
\text { Institutions as } \\
\text { Expressed by } \\
\text { Undergraduates }\end{array}$ & $\begin{array}{l}\text { Florence Adeoti } \\
\text { Yusuf, } \\
\text { Ayoade Ejiwale } \\
\text { Okanlawon \& } \\
\text { Taiwo Rukayat } \\
\text { Oladay (2017) }\end{array}$ & Nigeria & $\begin{array}{l}\text { Reka bentuk: } \\
\text { Kaedah } \\
\text { tinjauan } \\
\text { deskriptif }\end{array}$ & $\begin{array}{l}\text { Instrumen: } \\
\text { Soal selidik } \\
\text { berstruktur }\end{array}$ & $\begin{array}{l}\text { Hasil kajian menunjukkan bahawa usia mempengaruhi prestasi } \\
\text { akademik pelajar di institusi pengajian tinggi. } \\
\text { Hasilnya juga menyokong idea bahawa persekitaran pembelajaran } \\
\text { mempengaruhi prestasi akademik pelajar di institusi pengajian tinggi. } \\
\text { Perbezaan antara persepsi pelajar institusi terhadap faktor yang } \\
\text { mempengaruhi prestasi akademik pelajar di institusi pengajian tinggi } \\
\text { didapati tidak signifikan. }\end{array}$ \\
\hline
\end{tabular}


Dapatan kajian menunjukkan terdapat 4 faktor utama yang mempengaruhi pencapaian akademik iaitu faktor guru, faktor pelajar, faktor sekolah dan faktor persekitaran keluarga. Terdapat sub tema-sub tema yang mempengaruhi pencapaian akademik pelajar. Sub tema-sub tema bagi faktor guru adalah ciri-ciri guru dan strategi dan kaedah pengajaran guru. Sub tema-sub tema bagi faktor pelajar adalah seperti sikap pelajar, minat pelajar,motivasi pelajar untuk belajar,gaya pembelajaran dan kesihatan pelajar dari segi fizikal dan mental pelajar. Sub tema-sub tema bagi faktor sekolah adalah dari segi kepimpinan guru besar, pengetua atau pengarah, fasiliti-fasiliti di sekolah dan persekitaran sekolah. Sub tema-sub tema bagi faktor keluarga adalah seperti persekitaran keluarga, penglibatan ibu bapa dan latar belakang keluarga.

\begin{tabular}{|c|c|c|c|c|c|c|c|c|c|c|c|c|c|}
\hline \multirow[t]{2}{*}{ Pengarang } & \multicolumn{2}{|c|}{ Faktor guru } & \multicolumn{5}{|c|}{ Faktor pelajar } & \multicolumn{3}{|c|}{ Faktor sekolah } & \multicolumn{3}{|c|}{ Faktor keluarga } \\
\hline & CCG & KPG & SP & MP & MPB & GP & $\mathrm{KP}$ & KPP & FS & PS & PK & PIB & LBK \\
\hline $\begin{array}{l}\text { Munyaradzi Nyoni, } \\
\text { Thabani Nyoni \& } \\
\text { Wellington G. Bonga } \\
\text { (2017) }\end{array}$ & I & & & & & & & l & & 1 & & & I \\
\hline $\begin{array}{l}\text { Muhamad Shafiq \& } \\
\text { Norani (2018) } \\
\text { Hanifah Mahat et al. } \\
\text { (2017) }\end{array}$ & & & $\begin{array}{l}1 \\
1\end{array}$ & I & & I & & & & & & & \\
\hline $\begin{array}{l}\text { Tohol Simamora, Edi } \\
\text { Harapan \& Nila } \\
\text { Kesumawati }(2020)\end{array}$ & & & & I & I & & & & & & & & I \\
\hline $\begin{array}{l}\text { Melvin Anak } \\
\text { Maxwell \& Shahlan } \\
\text { Surat (2020) }\end{array}$ & & & & & & & & & & & & & l \\
\hline $\begin{array}{l}\text { Riska Yurnaliza \& } \\
\text { Totoh Andayono, } \\
\text { ST.(2019) }\end{array}$ & & & & I & l & I & l & & & 1 & I & & I \\
\hline $\begin{array}{l}\text { Lastri, Sri } \\
\text { Kartikowati \& } \\
\text { Sumarno }(2020)\end{array}$ & & & & I & l & & & & & & I & & \\
\hline $\begin{array}{l}\text { Mohd Erfy Ismail et } \\
\text { al. (2019) }\end{array}$ & & I & & 1 & & & & & & & & I & \\
\hline $\begin{array}{l}\text { Halimatus Saadiah } \\
\text { Kariya (2020) }\end{array}$ & & I & I & I & & & & & & & & & \\
\hline $\begin{array}{l}\text { Azza Salsabila \& } \\
\text { Puspitasari (2020) }\end{array}$ & & & & I & & & I & & I & I & & & \\
\hline $\begin{array}{l}\text { Muhammad Arshad, } \\
\text { Zia Ahmad Qamar \& } \\
\text { Faheem Huma Gulzar } \\
\text { (2018) }\end{array}$ & & & & & & & & & I & I & & & \\
\hline $\begin{array}{l}\text { Yung-hsun Cheng \& } \\
\text { Chia-wen Weng } \\
\text { (2017) }\end{array}$ & l & I & & & & & & I & & & & I & \\
\hline $\begin{array}{l}\text { Julaila Sapari \& } \\
\text { Abdul Halim } \\
\text { Abdullah (2019) }\end{array}$ & & I & I & I & & I & & & & l & & & \\
\hline $\begin{array}{l}\text { Seham Elashhab } \\
(2020)\end{array}$ & & I & & & & & & & & & & & \\
\hline $\begin{array}{l}\text { Halimah Maalip et al. } \\
\text { (2020) }\end{array}$ & & & I & & & & & & & & & & \\
\hline $\begin{array}{l}\text { Balaram Duwal \& } \\
\text { Lalita Khonju (2020) }\end{array}$ & & I & & & & & & & & & & & \\
\hline $\begin{array}{l}\text { Florence Adeoti } \\
\text { Yusuf, } \\
\text { Ayoade Ejiwale } \\
\text { Okanlawon \& } \\
\text { Taiwo Rukayat } \\
\text { Oladay (2017) }\end{array}$ & & & & & & & & & & I & & & \\
\hline
\end{tabular}


Nota:

$\quad$ Faktor Guru
CCG = Ciri-ciri
guru
KPG = Kaedah
atau strategi
pengajaran guru

$\quad$ Faktor Pelajar
SP = Sikap pelajar
MP= Minat pelajar
MPB= Motivasi
pelajar untuk belajar
GP= Gaya
pembelajaran
KP=Kesihatan
pelajar

\author{
Faktor Sekolah \\ $\mathrm{KPP}=$ Kepimpinan \\ pengetua, pengarah \\ atau guru besar \\ $\mathrm{FS}=$ Fasiliti sekolah \\ PS= Persekitaran \\ sekolah
}

\author{
Faktor Keluarga \\ PK= Persekitaran \\ Keluarga \\ PIB =Penglibatan ibu \\ bapa \\ LBK=Latar Belakang \\ Keluarga
}

\section{Faktor Guru}

Peranan guru sebagai seorang pembimbing dilihat daripada pelbagai aspek sama ada dari segi tahap kualiti, sikap guru dan kaedah pengajaran yang dilakukan dalam kelas. Guru yang berkualiti dapat meningkatkan komitmen pelajar dalam aktiviti pembelajaran serta penglibatan intelektual pelajar dalam proses pengajaran dan pembelajaran di dalam bilik darjah. Selain itu, guru berkualiti turut meningkatkan minat pelajar serta membentuk sikap pelajar yang positif dalam pembelajaran. Guru adalah salah satu tonggak utama dalam sistem penyampaian pengetahuan untuk pelajar dan kejayaan pelajar dalam pencapaian akademik. Oleh itu, peranan guru adalah sangat penting dalam menentukan kejayaan pelajar dalam prestasi akademik mereka. Berkaitan dengan tanggapan ini, sebanyak tujuh kajian didapati memusatkan perhatian pada faktor ini, terutamanya pada pengaruh guru terhadap pencapaian akademik pelajar. Di antara kajian sebelumnya yang disebutkan di atas, enam kajian menunjukkan bahawa kaedah pengajaran atau strategi pengajaran yang dilaksanakan oleh guru adalah faktor utama dalam tema ini yang mempengaruhi pencapaian akademik pelajar manakala dua kajian menunjukkan ciri-ciri guru mempengaruhi pencapaian akademik pelajar.

Dari aspek kaedah pengajaran atau strategi yang dilaksanakan oleh guru,enam daripada tujuh kajian melaporkan bahawa pencapaian pelajar dipengaruhi oleh kaedah pengajaran guru (Mohd Erfy et al. 2019 ; Halimatus, 2020 ; Julaila \& Abdul Halim, 2019 ; Seham, 2020 ; Balaram \& Lalita, 2020) . Selanjutnya, terdapat penyelidikan menyatakan bahawa kaedah yang diamalkan oleh guru dalam menyampaikan pengetahuan termasuk penggunaan aplikasi ICT, demonstrasi dan bahan pengajaran. Oleh itu, peningkatan ketara berlaku pada pemahaman dan pencapaian pelajar dalam mata pelajaran yang mereka pelajari. Dalam kajian yang dilaksanakan oleh Mohd Erfy et al. (2019) menyatakan bahawa guru perlu mempelbagaikan gaya pengajaran guru di dalam kelas. Guru kreatif dalam pengajaran di dalam kelas boleh menarik minat pelajar untuk menumpukan perhatian terhadap isi pelajaran yang ingin disampaikan oleh seorang guru. Oleh itu, ia dapat memberikan maklumat yang dapat difahami oleh pelajar. Instruksional yang berkesan memerlukan guru yang baik dan juga mampu memotivasikan pelajar dalam pembelajaran. Selain itu, guru mesti membuat arahan yang lebih jelas untuk pelajar supaya isi kandungan pelajaran lebih mudah difahami dan tidak mengelirukan. Dalam proses instruksional, guru mesti membangkitkan minat pelajar belajar, membimbing mereka dalam cara pembelajaran yang berkesan, menjelaskan keraguan, menolong mereka dalam menyelesaikan masalah, menyediakan bahan pengajaran dan meningkatkan penguasaan kemahiran mereka.

Dalam kajian Mohd Erfy Ismail et al. (2019) juga menyatakan bahawa dalam penggunaan alat bantu mengajar, guru perlu ambil inisiatif untuk mempelbagaikan arahan di dalam kelas agar pelajar dapat menarik lebih banyak tumpuan terhadap pengajaran guru. Daya tarikan pengajaran bergantung pada kemahiran dan kaedah pengajaran guru. Gaya pengajaran guru di dalam kelas boleh memberi kesan kepada pembelajaran pelajar dan pencapaian akademik .

Selain itu, empat kajian yang dilakukan di Malaysia, Taiwan, Nepal, dan Saudi Arabia melaporkan bahawa peralihan kaedah pengajaran tradisional kepada penggunaan pengajaran digital dapat memotivasikan pembelajaran dan meningkatkan pencapaian pembelajaran (Halimatus, 2020 ; Yunghsun Cheng \& Chia-wen Weng, 2017; Seham, 2020 ; Balaram \& Lalita, 2020). Kajian yang telah dilaksanakan oleh Halimatus (2020) telah mendapati beberapa komponen yang bersesuaian boleh dilaksanakan bagi menarik minat kepada sesi pembelajaran dan pengajaran seperti melalui video, virtual 
simulation dan penggunaan teknologi secara atas talian iaitu Kahoot, Quizizz, Youtube, Animation dan lain-lain pendekatan yang bersesuaian. Justeru, pendekatan dan kaedah terbaik yang digunakan menyumbang ke arah pencapaian akademik yang cemerlang bagi pelajar. Dalam kajian yang dijalankan oleh Yung-hsun Cheng \& Chia-wen Weng (2017) telah menunjukkan bahawa sikap guru terhadap pengajaran media digital mempengaruhi pencapaian pembelajaran pelajar. Kajian ini mendapati bahawa teknologi digital interaktif menawarkan peluang kepada pelajar belajar secara kolaboratif. Kajian ini juga telah menunjukkan pelbagai kesan penggunaan digital pada pelajar termasuk peningkatan pemahaman tentang kandungan pembelajaran, kesediaan untuk meneroka, dan kemampuan untuk berfikir secara kritis. Dalam kajian Seham (2020), penggunaan strategi motivasi guru mesti sesuai dengan suasana bilik darjah dan keperluan dan mental pelajar. Guru harus mewujudkan persekitaran kelas yang bermotivasi dengan melibatkan pelajar mereka dalam tugas yang berbeza.

Dari aspek ciri-ciri guru, dua kajian melaporkan bahawa ia mempengaruhi pencapaian akademik pelajar (Munyaradzi, Thabani \& Wellington, 2017; Yung-hsun Cheng \& Chia-wen Weng, 2017). Ia adalah umum diketahui bahawa pelajar mempunyai interaksi dan hubungan yang rapat dengan guru mereka. Oleh itu, pengaruh ini boleh berlaku dalam interaksi harian antara guru dan pelajar. Selain itu, didapati bahawa prestasi akademik pelajar meningkat apabila guru menunjukkan rasa hormat kepada pelajar semasa berinteraksi dengan mereka di dalam kelas. Guru haruslah mendengar pandangan dan idea pelajar supaya pelajar rasa mereka dihormati dan idea atau pandangan mereka didengari . Prestasi pelajar meningkat ketika mereka rasa dihormati oleh para guru. Di samping itu, hubungan antara guru dan pelajar mesti berada dalam keadaan baik supaya pelaksanaan hubungan yang baik ini akan menjadikan pelajar lebih selesa dan yakin untuk mengemukakan soalan yang tidak difahami.

\section{Faktor Pelajar}

Usaha pelajar terhadap pencapaian akademik ditentukan oleh tahap penglibatan dan dedikasi mereka dalam pembelajaran. Terdapat beberapa faktor yang mempengaruhi usaha pelajar untuk meningkatkan pencapaian akademiknya. Oleh itu, didapati bahawa pelajar merupakan salah satu faktor yang mempengaruhi pencapaian akademik mereka. Secara umum, lima sub tema adalah diperoleh di bawah faktor ini. Secara lebih spesifik, lima kajian menunjukkan sikap pelajar mempengaruhi pencapaian akademik, lapan kajian menunjukkan minat pelajar mempengaruhi pencapaian akademik pelajar, tiga kajian menunjukkan motivai pelajar untuk belajar mempengaruhi pencapaian akademik mereka, tiga kajian menunjukkan gaya pembelajaran mempengaruhi pencapaian akademik pelajar dan dua kajian menunjukkan kesihatan pelajar dari segi fizikal dan mental mempengaruhi pencapaian akademik pelajar.

Dari aspek sikap pelajar, lima kajian menunjukkan sikap pelajar mempengaruhi pencapaian akademik pelajar (Muhamad Shafiq \& Norani 2018; Hanifah et al. 2017; Halimatus, 2020; Julaila \& Abdul Halim, 2019; Halimah et al., 2020). Kajian oleh Muhamad Shafiq dan Noraini (2018) menunjukkan pelajar yang mempunyai sikap yang baik dalam pembelajaran akan mendapat pencapaian akademik yang tinggi. Selain itu, kajian oleh Hanifah et al. (2017) menunjukkan sikap pelajar mampu mempengaruhi pencapaian akademik pelajar. Hal ini bermakna sikap seseorang pelajar berhubungan dengan pencapaiannya sama ada pelajar itu mempunyai sikap yang positif atau sikap yang negatif. Dapatan kajian mendapati bahawa pelajar yang mempunyai sikap negatif terhadap mata pelajaran geografi boleh menyebabkan pencapaiannya rendah dan sebaliknya pelajar yang mempunyai sikap yang positif boleh mendapat pencapaian yang tinggi. Ringkasnya, sikap pelajar terhadap mata pelajaran geografi mahupun mata pelajaran lain adalah sangat penting kerana ia boleh mempengaruhi pencapaiannya secara tidak langsung melalui tindakannya. Kajian oleh Halimatus (2020) menyatakan pencapaian akademik pelajar dipengaruhi oleh sikap dan sahsiah. Nilai tanggungjawab dan amanah pelajar kepada tugasan yang diberikan mempengaruhi prestasi pencapaian akademik pelajar ke arah yang lebih baik. Dapatan juga diperolehi daripada kenyataan responden bertepatan sikap iaitu rajin mengulang kaji, fokus ketika dalam proses pembelajaran, membuat catatan dan nota ringkas agar lebih mudah difahami. Di samping itu, kajian yang dilaksanakan oleh Seham (2020) mendapati pelajar sentiasa memberi tumpuan di dalam kelas selain sering berbincang permasalahan bersama rakan dan sentiasa berusaha menyiapkan tugasan yang diberi. Hal ini kerana mereka menyedari sikap yang sedemikian akan dapat meningkatkan kefahaman dan pencapaian mereka. Seperti yang dinyatakan oleh Seham (2020) yang mendapati sikap, 
komitmen dan pelajar yang berwawasan tinggi akan memberi rangsangan yang baik dalam pencapaian akademik. Dalam kajian Yusuf, Okanlawon dan Oladay (2017) mendapati bahawa kehadiran pelajar mempengaruhi prestasi akademik pelajar. Hal ini menunjukkan bahawa sekiranya pelajar kerap mengikuti kelas, mereka akan mempunyai prestasi akademik yang baik.

Dari aspek minat pelajar, terdapat lapan kajian menunjukkan minat pelajar mempengaruhi pencapaian akademik pelajar (Muhamad Shafiq \& Norani, 2018; Tohol, Edi \& Nila, 2020; Riska \& Totoh, 2019; Lastri, Sri Kartikowati \& Sumarno, 2020; Mohd Erfy et al., 2019 ; Halimatus, 2020; Azza \& Puspitasari 2020; Julaila \& Abdul Halim, 2019). Dalam kajian Muhamad Shafiq dan Noraini (2018) mendapati bahawa sekiranya pelajar mempunyai minat yang tinggi dalam pembelajaran, maka pencapaian mereka akan rendah. Begitu juga sebaliknya jika minat pelajar adalah rendah dan sederhana, maka pencapaian mereka akan tinggi. Pada pandangan pengkaji, kemungkinan perkara ini berlaku disebabkan oleh pelajar yang mempunyai minat yang tinggi, mereka terlalu yakin boleh berjaya dengan mudah. Oleh yang demikian, mereka mengambil sikap sambil lewa ketika menjawab peperiksaan. Bagi pelajar yang kurang minat dalam pembelajaran, mereka akan cuba untuk meningkatkan pencapaian mereka pada tahap yang terbaik ketika menduduki peperiksaan. Motivasi ini memainkan peranan penting bagi mereka untuk memperoleh pencapaian yang terbaik dalam akademik. Hasil kajian oleh Lastri, Sri Kartikowati dan Sumarno (2020) menunjukkan bahawa minat pelajar terhadap kursus tersebut dicerminkan dalam proses pembelajaran pelajar. Kajian ini menyatakan minat yang timbul pada seseorang pelajar akan mempengaruhi proses pembelajaran dan pencapaian akademiknya. Di samping itu, penglibatan dalam pengajaran dan pembelajaran adalah salah satu perkara yang perlu untuk memastikan bahawa pelajar sama ada minat atau tidak. Kajian ini juga menyatakan minat pelajar untuk belajar akan mendorong pelajar berfikir secara kritikal. Selain itu, pelajar akan aktif di dalam kelas, bersedia untuk bekerja berkumpulan dan akan meningkatkan kemahiran berinteraksi dan berkomunikasi.

Dari aspek motivasi pelajar, terdapat tiga kajian menunjukkan motivasi pelajar untuk belajar mempengaruhi pencapaian akademik (Tohol, Edi \& Nila 2020; Riska \& Totoh, 2019; Lastri, Sri Kartikowati \& Sumarno 2020). Dalam kajian Tohol, Edi dan Nila (2020) menunjukkan bahawa motivasi belajar mempunyai pengaruh yang signifikan terhadap pencapaian pembelajaran. Kajian oleh Riska dan Totoh (2019) melaporkan bahawa kekurangan motivasi untuk subjek dan pembelajaran berdasarkan arahan kelas adalah faktor-faktor yang mempengaruhi pencapaian akademik pelajar. Kajian ini juga mendapati bahawa penghargaan daripada guru mendorong para pelajar untuk meluangkan lebih banyak masa untuk belajar, membantu mereka menunjukkan prestasi yang lebih baik dalam mata pelajaran mereka. Kajian oleh Lastri, Sri Kartikowati dan Sumarno (2020) menyatakan interaksi positif antara guru dan pelajar meningkatkan tahap komitmen dan motivasi mereka terhadap tugasan akademik mereka.

Dari aspek gaya pembelajaran, terdapat tiga kajian yang menunjukkan gaya pembelajaran mampu mempengaruhi pencapaian akdemik mereka (Muhamad Shafiq \& Norani, 2018; Riska \& Totoh, 2019; Julaila \& Abdul Halim, 2019). Kajian oleh Muhamad Shafiq dan Noraini (2018) menyatakan sekiranya pelajar memiliki kaedah pembelajaran yang baik, maka pencapaian mereka akan rendah. Begitu juga sebaliknya jika kaedah pembelajaran pelajar itu adalah rendah dan sederhana, maka pencapaian mereka akan tinggi. Pada pengamatan pengkaji, kemungkinan perkara ini berlaku juga disebabkan oleh pelajar tersebut terlalu yakin yang mereka mampu untuk berjaya mencapai keputusan yang terbaik. Walau bagaimanapun, kaedah pembelajaran yang terbaik sahaja tidak mampu untuk mencapai kecemerlangan dalam akademik sekiranya pelajar tersebut mempunyai sikap ambil mudah dan terlalu yakin bahawa jawapan yang diberikan itu adalah menepati kehendak pensyarah. Kajian oleh Julaila dan Abdul Halim (2019) menunjukkan pelajar menyukai pemberian tugasan dan nota-nota oleh pensyarah dan pembelajaran akan dilakukan secara berkumpulan. Mereka juga akan merujuk kepada pensyarah jika tidak memahami pembelajaran mereka. Hal ini jelas menunjukkan mempunyai gaya pembelajaran seperti ini dapat mempengaruhi pencapaian mereka kerana mereka akan lebih memahami pengajaran dengan lebih cepat. Sebagai seorang pengajar juga haruslah membantu pelajar-pelajarnya menggunakan gaya pembelajarannya dengan baik. Pelajar mendapati bahawa dengan menggunakan bahasa pengantar dan penerangan yang mudah dengan latihan dan nota yang mencukupi, perbincangan secara kumpulan dapat menjadikan Matematik Kejuruteraan sebagai satu mata pelajaran yang menarik dan bermakna. 
Dari aspek kesihatan pelajar, terdapat dua kajian yang menunjukkan kesihatan pelajar dari segi fizikal dan mental mampu mempengaruhi pencapaian akademik pelajar. Kajian yang dilaksanakan oleh Riska dan Totoh (2019) serta Azza dan Puspitasari (2020) menunjukkan kesihatan fizikal dan rohani memberi kesan terhadap prestasi pembelajaran pelajar. Apabila seseorang pelajar tidak mempunyai kesihatan yang baik dari segi fizikal, mental dan rohani, hal ini boleh menyebabkan pelajar tersebut hilang minat dan motivasi untuk belajar dan menyebabkan prestasi pencapaian akademik pelajar akan semakin menurun.

\section{Faktor sekolah}

Sekolah mempengaruhi peningkatan akademik dan sosial pelajar, terutamanya pencapaian akademik pelajar melalui struktur sekolah, kakitangan, organisasi, sumber, dan persekitaran sekolah. Terdapat tujuh kajian yang menunjukkan faktor sekolah mempengaruhi pencapaian akademik pelajar. Secara spesifik, terdapat tiga sub tema dalam faktor ini iaitu kepimpinan pengetua atau guru besar sekolah, fasiliti-fasiliti sekolah dan persekitaran sekolah. Terdapat dua kajian menunjukkan kepimpinan pengetua atau guru besar mempengaruhi pencapaian akademik pelajar, dua kajian yang menyatakan fasiliti-fasiliti sekolah mempengaruhi pencapaian akademik pelajar dan enam kajian menunjukkan persekitaran sekolah mempengaruhi pencapaian akademik pelajar.

Dari aspek kepemimpinan, terutamanya peranan pengetua atau guru besar, dua kajian melaporkan bahawa pencapaian akademik pelajar dipengaruhi oleh kepemimpinan pengetua sekolah (Munyaradzi \& Wellington, 2017; Yung-hsun Cheng \& Chia-wen Weng 2017). Kajian oleh Yung-hsun Cheng dan Chia-wen Weng (2017) mendapati bahawa hubungan antara kepemimpinan pengetua dan tahap komitmen guru menjadi tinggi. Difahami bahawa kepemimpinan pengetua yang baik dapat mendorong guru untuk menerima dasar baru pendidikan, seperti menggunakan kaedah atau teknologi baru untuk mengajar. Oleh itu, pengetua harus menggunakan kekuatan kepemimpinannya untuk mengembangkan komitmen guru. Kajian ini juga menunjukkan bahawa kepemimpinan utama memotivasikan pengikut untuk mengatasi kepentingan diri sendiri demi perubahan sikap dan strategi pengajaran. Kajian oleh Munyaradzi, Thabani dan Wellington (2017) mendapati bahawa sekolah harus mengatur program pendidikan untuk membantu pemahaman, kebolehan, dan sumber daya ibu bapa pelajar untuk memberi sokongan yang lebih baik untuk pendidikan anak-anak mereka di sekolah. Kajian ini juga mendapati bahawa bentuk pendidikan ini dapat membantu perkembangan sikap positif pelajar terhadap subjek tersebut. Kajian ini menunjukkan bahawa kepemimpinan pengetua sekolah mempunyai hubungan yang signifikan dengan pencapaian akademik pelajar. Mereka juga melaporkan pengetua sekolah itu memainkan peranan penting dalam mendorong pembaharuan dalam pendidikan.

Dari aspek fasiliti sekolah, dua kajian menunjukkan faktor fasiliti di sekolah dapat mempengaruhi pencapaian akademik pelajar (Azza \& Puspitasari, 2020; Muhammad Arshad, Zia \& Faheem 2018). Kajian Azza dan Puspitasari (2020) menyatakan prasarana di sekolah seperti ruang kelas dengan penerangan, ventilasi udara yang cukup baik, tersedianya penghawa dingin, LCD projektor, papan tulis (papan putih), perpustakaan lengkap dan laboratori dapat mempengaruhi pencapaian akademik pelajar. Kelengkapan prasarana akan memberi pengaruh positif terhadap pencapaian akademik pelajar. Kajian oleh Muhammad Arshad, Zia dan Faheem (2018) menunjukkan bahawa pengudaraan, tanaman, taman permainan, kotak perubatan pertolongan cemas, LCD projektor sangat mempengaruhi pencapaian akademik pelajar.

Dari aspek persekitaran sekolah, enam kajian menunjukkan faktor persekitaran sekolah mempengaruhi pencapaian akademik pelajar. Kajian oleh Azza dan Puspitasari (2020) mendapati bahawa persekitaran sekolah dan kelas yang kondusif memacu pelajar untuk berghairah dalam pembelajaran dan mampu mencapai prestasi akademik yang baik. Dalam kajian Julaila dan Abdul Halim (2019) menyatakan bahawa faktor persekitaran sekolah mempengaruhi pencapaian akademik pelajar. Pelajar amat mementingkan pencahayaan, bilik kuliah yang kondusif, bersih dan teratur selain mempunyai bahan rujukan yang banyak di perpustakaan. Hal ini kerana persekitaran yang sedemikian dapat memberi keselesaan dalam pembelajaran kursus Matematik Kejuruteraan. Bahan rujukan yang banyak juga akan dapat membantu mereka menyiapkan latihan dan tugasan yang diberikan oleh pensyarah selain untuk 
mengulangkaji pelajaran. Hal ini jelas menunjukkan faktor persekitaran sekolah adalah salah satu faktor yang mempengaruhi pencapaian akademik pelajar.

\section{Faktor keluarga}

Struktur keluarga adalah salah satu faktor yang mempengaruhi pencapaian akademik pelajar. Terdapat tujuh kajian yang memfokuskan fator keluarga dari segi persekitaran keluarga, penglibatan ibu bapa dan latar belakang keluarga mempengaruhi pencapaian akademik pelajar. Dua kajian yang menyatakan persekitaran keluarga mempengaruhi pencapaian akademik pelajar, dua kajian menyatakan penglibatan ibu bapa mempengaruhi pencapaian akademik pelajar dan empat kajian yang menunjukkan latar belakang keluarga mempengaruhi pencapaian akademik pelajar.

Dari aspek faktor persekitaran keluarga, dua kajian menyatakan persekitaran keluarga memainkan peranan yang penting dalam pencapaian akademik pelajar (Lastri, Sri Kartikowati, Sumarno, 2020; Riska \& Totoh, 2019). Dalam kajian Lastri, Sri Kartikowati dan Sumarno (2020) menyatakan bahawa persekitaran keluarga mempunyai kesan yang signifikan ke arah pencapaian akademik pelajar.

Dari aspek penglibatan ibu bapa, dua kajian menunjukkan penglibatan ibu bapa memainkan peranan yang penting dalam pencapaian akademik pelajar (Yung-hsun Cheng \& Chia-wen Weng, 2017; Mohd. Erfy Ismail et al., 2019). Kajian oleh Mohd. Erfy et al. (2019) menyatakan bahawa penglibatan ibu bapa dari segi mendorong dan membantu pelajar membuat kerja rumah ditunjukkan sebagai sesuatu yang dapat memberi kesan yang baik terhadap pencapaian pelajar. Kajian ini juga mendapati penglibatan ibu bapa dalam kerja rumah pelajar yang diberikan oleh guru di sekolah akan menjadikan pelajar meningkatkan pencapaian akademik mereka di sekolah. Pemantauan ibu bapa terhadap tugas yang diberikan oleh guru juga dapat membantu pelajar lebih memahami dengan lebih jelas dan memperoleh pencapaian yang baik. Dengan adanya penglibatan ibu bapa dalam pendidikan anak-anak, terutamanya pemantauan di rumah dan di sekolah, ibu bapa dapat mengubah tingkah laku anak untuk mencapai kejayaan. Dapatan kajian juga menyatakan bahawa penglibatan ibu bapa tidak berakhir di rumah, tetapi ibu bapa harus bekerjasama dengan guru supaya kedua-duanya dapat memahami dan mencapai kejayaan atau persetujuan dalam usaha meningkatkan pencapaian akademik pelajar. Kajian yang dilakukan di Taiwan melaporkan bahawa kebanyakan model ibu bapa yang berkaitan dengan pencapaian pelajar tinggi adalah model yang memberi tumpuan dalam mengawasi proses pembelajaran anak-anak mereka. Pergaulan yang paling berkesan dijumpai ketika keluarga mempunyai harapan akademik yang tinggi untuk anak-anak mereka, di mana mereka mengembangkan dan mengekalkan komunikasi yang baik dengan anak-anak mengenai aktiviti sekolah dan membantu anak-anak mereka untuk mengembangkan tabiat membaca yang sihat.

Dari segi latar belakang keluarga, satu kajian yang dilakukan di Indonesia oleh Tohol, Edi dan Nila (2020) melaporkan bahawa tahap pendidikan ibu bapa mempunyai pengaruh yang signifikan terhadap pencapaian pembelajaran pelajar. Ibu bapa yang berpendidikan tinggi akan memahami bahawa kejayaan pembelajaran anak-anak mereka tidak hanya bergantung pada guru dan sekolah tetapi juga dipengaruhi oleh persekitaran keluarga dan ibu bapa, sehingga ibu bapa menyediakan persekitaran pembelajaran,kemudahan dan sokongan yang baik. Ibu bapa yang mempunyai latar belakang pendidikan yang rendah dalam mendidik anak-anak mereka mempunyai pengetahuan yang terhad jika dibandingkan dengan ibu bapa yang mempunyai tahap pendidikan yang tinggi. Semakin tinggi tahap pendidikan seseorang, semakin tinggi pengetahuannya sehingga pelbagai tingkah laku ibu bapa dalam membimbing, memberi arahan dan memberi motivasi kepada anak-anak. Hal ini secara tidak langsung dapat mempengaruhi pencapaian akademik pelajar.

\section{Perbincangan Kajian}

Tinjauan literatur bersistematik ini menyatakan bahawa empat faktor yang telah dibincangkan sebelumnya iaitu faktor guru, faktor pelajar, faktor sekolah dan faktor keluarga mempengaruhi pencapaian pelajar. Selain itu, terdapat kesan positif dan kesan negatif dari faktor-faktor ini yang mempengaruhi pencapaian akademik pelajar. Selanjutnya, faktor-faktor ini berkait rapat antara satu 
sama lain. Hal ini dapat dilihat dari bagaimana ciri-ciri positif, pengalaman, dan tingkah laku guru di dalam kelas memberikan sumbangan positif terhadap persekitaran pembelajaran pelajar. Persekitaran pengajaran dan pembelajaran yang baik dan memotivasikan dapat meningkatkan pencapaian akademik pelajar. Menurut Munyaradzi, Thabani dan Wellington (2017), sehubungan dengan pengalaman guru dan pencapaian akademik pelajar, hipotesis lazim hadir mengenai perkaitan antara pencapaian akademik pelajar yang tinggi dengan guru yang paling berpengalaman atau berkelayakan. Hal ini disebabkan oleh bahan dan kemahiran kepemimpinan yang dikuasai oleh guru yang berkelayakan ini untuk menguruskan pelbagai masalah bilik darjah.

Arahan mempunyai kaitan yang rapat dengan persekitaran bilik darjah. Hal ini dapat dilihat dengan jelas bahawa kualiti arahan yang disampaikan oleh guru mempengaruhi minat pelajar terhadap mata pelajaran mereka. Khususnya, pembelajaran yang berstruktur dengan baik akan menghasilkan kesan yang positif bagi para pelajar. Arahan yang menekankan pertumbuhan konseptual memudahkan kemahiran belajar, pemahaman konsep dan pengetahuan pelajar. Bagi pelajar, pentingnya guru dan ibu bapa untuk menghargai prestasi pelajar kerana ini akan mendorong para pelajar menghabiskan lebih banyak masa untuk belajar. Penghargaan ini akan menjadi motivasi mereka untuk berusaha lebih keras belajar dan juga untuk mengekalkan keputusan mereka dan mengelakkan kekecewaan daripada ibu bapa dan guru mereka. Selain itu, prestasi pelajar akan meningkat apabila mereka dihormati dan dihargai oleh guru (Yung-hsun Cheng \& Chia-wen Weng, 2017). Secara keseluruhan, rasa hormat dan kepercayaan harus ada dalam interaksi antara guru dan pelajar.

Selain faktor guru dan pelajar, didapati juga faktor sekolah dan keluarga memberi kesan yang besar terhadap pencapaian akademik pelajar. Dari aspek kepimpinan, pengetua atau guru besar sekolah memainkan peranan penting dalam mempromosikan pelbagai kaedah pengajaran dan pembelajaran dalam pendidikan. Pada asasnya, kepimpinan dilaksanakan oleh pengetua atau guru besar untuk mendorong guru meningkatkan prestasi mereka dengan memberikan mereka kursus yang berkaitan dengan apa yang mereka perlukan untuk peningkatan prestasi mereka. Lebih-lebih lagi, program pendidikan dapat dibentuk melalui amalan kepemimpinan yang betul supaya ibu bapa dapat memperoleh pengetahuan, kemahiran, dan sumber untuk menyokong dan membantu anak-anak mereka dalam pendidikan. Penglibatan keluarga juga akan mempengaruhi sikap pelajar terhadap pembelajaran, terutama bagi ibu bapa yang prihatin terhadap pencapaian anak-anak mereka. Selain itu, ahli keluarga terutamanya ibu bapa yang mempunyai maklumat mengenai peluang pekerjaan pada masa depan pasti akan mendorong para pelajar untuk berusaha dan mendapatkan prestasi yang baik di sekolah supaya mereka lebih senang dapat peluang pekerjaan yang baik.

Selain daripada kesan positif, kesan negatif dapat berlaku terhadap pencapaian pelajar melalui faktorfaktor tersebut. Sekiranya bahan pengajaran atau alat bantu mengajar yang digunakan oleh guru dalam pengajaran mereka tidak menarik atau memenuhi keperluan pelajar, hal ini akan menyebabkan kebosanan pelajar dalam pembelajaran dan mereka tidak dapat menumpukan sepenuh perhatian terhadap pengajaran dan pembelajaran tersebut. Oleh itu, prestasi akademik mereka akan terjejas secara negatif. Selain itu, guru yang menumpukan perhatian kepada kumpulan pelajar tertentu akan membawa kesan negatif terhadap sikap pelajar. Begitu juga, hal ini akan menyebabkan jangka masa tumpuan pelajar dalam pengajaran dan pembelajaran yang rendah dan interaksi yang rendah antara guru dan pelajar. Hasil ini juga mungkin menyebabkan pelajar kurang menghormati guru. Selain itu, sikap negatif pelajar terhadap subjek tersebut akan mempengaruhi prestasi akademik mereka. Pada zaman teknologi ini, kes menjadi lebih serius di mana pelajar lebih menumpukan perhatian pada telefon bimbit, permainan video dan hiburan mereka berbanding pelajaran mereka. Selain itu, pelajar yang lewat tidur akan menyebabkan pelajar lewat ke sekolah dan mengantuk di sekolah semasa sesi pengajaran dan pembelajaran. Mereka juga mungkin terlepas dengan maklumat penting tentang topik yang dipelajari pada hari tersebut kerana mereka tidak akan hadir ke sekolah sepanjang hari.

Prestasi akademik yang lemah di kalangan pelajar juga disebabkan oleh sokongan dari sekolah dan keluarga yang tidak mencukupi. Ia boleh dapat dilihat dengan jelas bahawa persekitaran sekolah yang tidak menyediakan ruang yang kondusif untuk proses pembelajaran pelajar akan memberi kesan buruk terhadap pencapaian akademik mereka. Oleh itu, pengetua sekolah harus mengambil berat persekitaran sekolah termasuk guru, pelajar, dan staf-staf sekolah. Pengetua atau guru besar sekolah yang kurang 
ambil peduli terhadap keperluan dan keadaan pelajar akan membawa kepada keadaan yang lebih buruk. Lebih-lebih lagi, dengan hubungan yang lemah antara sekolah dan ibu bapa, kesan negatif akan berlaku terhadap prestasi akademik pelajar dan sikap pelajar. Dalam kajian oleh Munyaradzi, Thabani dan Wellington (2017) didapati bahawa status sosioekonomi keluarga yang rendah tidak dapat memberi sokongan sepenuhnya kepada anak-anak mereka dari segi keperluan untuk pendidikan pelajar dan hal ini menyebabkan prestasi yang buruk dalam peperiksaan mereka. Oleh itu, boleh dikatakan bahawa latar belakang keluarga memainkan peranan penting dalam isu ini. Namun begitu, keadaan buruk ini tidak akan berlaku sekiranya ibu bapa dan sekolah memainkan peranan mereka dalam memantau pelajaran anak-anak mereka.

\section{Kesimpulan}

Ulasan literatur bersistematik ini sedikit sebanyak membantu memberi pencerahan tentang faktor-faktor yang mempengaruhi pencapaian akademik pelajar. Empat tema utama yang mewakili faktor-faktor yang mempengaruhi pencapaian pelajar dikenal pasti berdasarkan tinjauan sistematik yang dilakukan oleh kajian ini. Secara khusus, tema pertama adalah faktor guru, khususnya dalam aspek ciri guru dan kaedah atau strategi pengajaran. Tema kedua adalah faktor pelajar yang dikembangkan berdasarkan sikap, minat, motivasi, gaya pembelajaran dan kesihatan pelajar. Tema ketiga dikenal sebagai faktor sekolah, yang secara khusus adalah kepemimpinan, fasiliti sekolah dan persekitaran sekolah. Sementara itu, tema keempat adalah faktor keluarga, yang merujuk kepada persekitaran keluarga, penglibatan ibu bapa dan latar belakang keluarga. Secara keseluruhan, faktor-faktor ini merupakan faktor utama yang mempengaruhi pihak berkepentingan terutama di sekolah dan institusi pendidikan. Dengan mengembangkan lagi faktor-faktor ini melalui penyatuan penemuan pelbagai hasil penyelidikan, pihak berkepentingan dapat menerima bantuan untuk memperbaiki faktor-faktor yang mempengaruhi yang sesuai dengan keperluan, kemampuan, dan minat para pelajar.

\section{Rujukan}

Azza Salsabila \& Puspitasari. (2020). Faktor-faktor Yang Mempengaruhi Prestasi Belajar Siswa Sekolah Dasar. Jurnal Pendidikan dan Dakwah 2(2), 278-288. https://ejournal.stitpn.ac.id/index.php/pandawa

Atchia, S. M. C., \& Chinapah, V. (2019). Factors affecting academic achievement of secondary school students in Mauritius. Journal of Education and Research, 9(1), 70-90. https://doi.org/10.3126/jer.v9i1.28825

Balaram Duwal \& Lalita Khonju. (2020). Factors Affecting Students' Academic Performance: The Case Of Students At Community Colleges In Bhaktapur District. International Research Journal of Management Science, 5(1): 23-38. http://www.ncm.edu.np

Dhakal, K. R. (2020). Factors affecting academic performance of Ssudents at community secondary school in Nepal. Merit Research Journal of Education and Review, 8(9), 165-170. https://doi.org/10.5281/zenodo.4057006

Florence Adeoti Yusuf, Ayoade Ejiwale Okanlawon \& Taiwo Rukayat Oladayo. (2020). Investigation into Factors Affecting Students' Academic Performance in Tertiary Institutions as Expressed by Undergraduates. Journal of Education in Black Sea Region, 5 (2), 62-75. Doi: 10.31578/jebs.v5i2.200 [1 Julai 2021].

Hafizah Abdul Razak (2015). Hubungan Antara Big Five Terhadap Pencapaian Akademik Pelajar, Universiti Malaysia Sarawak (UNIMAS).

Halimah Maalip, Azizi Yahaya, Koay Ting Yin, Balan Rathakrishnan, Ismail Maakip, Hanun Ahmad, Zaliha Mohammad Ali \& Norlaily Ahmad. (2020). Pembentukan Modal Insan: Hubungan Konsep Kendiri, Personaliti dan Pencapaian Akademik Pelajar Sekolah Menengah. Southeast Asia Psychology Journal, 8(2), 103-122. https://www.researchgate.net/publication/346717898

Halimatus Saadiah Kariya. (2020). Faktor-Faktor Yang Mempengaruhi Pencapaian Akademik Pelajar Politeknik METrO Betong Sarawak. Jurnal Dunia Pendidikan, 2(4), 9-18. http://myjms.mohe.gov.my/index.php/jdpd 
Hanifah Mahat, Paulin Chang Poh Ling, Nasir Nayan, Mohmadisa Hashim \&Yazid Saleh. (2017). Pencapaian Pelajar dalam Mata Pelajaran Geografi Sekolah Menengah di Sabah.Jurnal Sains Humanika, 9(2), 1-7. https://www.researchgate.net/publication /317785360_Pencapaian_Pelajar_ dalam_Mata_Pelajaran_Geografi_Sekolah_Menengah_di_Sabah_-_Analisis_Awal

Ismail, M. R., Ghazali, A. R., Abdul Latif, K. A., Maromar, F., \& Man, S. (2020). Hubungan Antara Faktor Dalaman dan Faktor Luaran Dalam Mempengaruhi Kemahiran Menulis Bahasa Arab Pelajar di Institusi Pengajian Tinggi Malaysia. E-Jurnal Bahasa Dan Linguistik (e-JBL), 2(1), 112. http://ejbl.kuis.edu.my/index.php/e-jbl/article/view/29

Julaila Sapari \& Abdul Halim Abdullah. (2019). Faktor-Faktor Yang Mempengaruhi Pencapaian Kursus Matematik Kejuruteraan 1 Dalam Kalangan Pelajar Politeknik di Johor. Jurnal Sains Sosial 209-224. https://www.researchgate.net/publication/330934201

Lastri, Sri Kartikowati \& Sumarno. (2020). Factors that Influence Student Learning Achievement. Journal of Educational Sciences, 4(3), 679-693. https://www.researchgate.net/publication/343192741_Analysis_of_Factors_that_Influence_Stude nt_Learning_Achievement

Mahato, S. (2018). Leaning environment and students' achievement in Nepalese Business School. International Journal of Current Research, 10(12), 76763-76769. https://doi.org/10.24941/ijcr.33616.12.2018

M. Aydeniz, E. Kaya. (2012). Factors impacting turkish students' attitudes towards science and their academic performance in science. Journal of Turkish Science Education, 9(2), 25-48.

Melvin \& Shahlan Surat. (2020). Pengaruh Latar Belakang Keluarga Dan Pencapaian Akademik Pelajar Di SMK Bau. Jurnal Dunia Pendidikan, 2(1), 227-233. http://myjms.mohe.gov.my/index.php/jdpd/article/view/8931

Mohd Erfy Ismail et al. (2019). Factors that Influence Students' Learning: An observation on Vocational College students. Journal of Technical Education and Training, 11(1), 93-99. https://doi.org/10.30880/jtet.2019.11.01.12

Muhamad Shafiq \& Noraini. (2018). Mengenalpasti Faktor-Faktor Yang Mempengaruhi Pencapaian Akademik Pelajar Sarjana Muda Psikologi, Kolej Universiti Islam Melaka (KUIM). Jurnal Sains Sosial, 7, 77-87. https://kuim.edu.my/journal /index.php/JSS/article/view/466

Munyaradzi Nyoni, Thabani Nyoni \& Wellington G. Bonga. (2017). Factors Affecting Students' Academic Achievement in Zimbabwe's Rural Secondary Schools: A Case Study of Marimasimbe Secondary School in Jiri Community. Journal of Economics and Finance (DRJ-JEF), 2(3), 1-15. https://www.researchgate.net/publication/315767454

Muhammad Arshad, Zia Ahmad Qamar \& Faheem Huma Gulzar. (2018). Effects of Physical Facilities at Public Schools on Students' Achievement in Punjab, Pakistan. Journal Global Social Sceinces, 3(4), 102-113. http://dx.doi.org/10.31703/gssr. 2018(III-IV).07

Mushtaq, I., \& Khan, S. N. (2012). Factors sffecting Students' academic perfromace. Annual Conference of the North American Fuzzy Information Processing Society - NAFIPS, 12(9),1622. https://globaljournals.org/GJMBR_Volume12/3-Factors-Affecting-Students-Academic.pdf

Norasmah Othman. (2017). Daya Tahan Pelajar Universiti Awam dan Universiti Swasta. Jurnal Pendidikan Malaysia, 42(1), 77-86. https://ejournal.ukm.my/jpend/article/view/19601

Riska Yurnaliza \&Totoh Andayono, ST. (2019). Faktor-Faktor Yang Mempengaruhi Hasil Belajar Mahasiswa Bidikmisi Fakultas Teknik Universitas Negeri Padang.Cived Jurusan Teknik Sipil, 6(4). http://ejournal.unp.ac.id/index.php/cived/article/view/107046

Seham Elashhab. (2020). Motivational Teaching Strategies within Saudi University EFL Classrooms: How to Improve Students' Achievement? International Journal of Language and Literary Studies, 2(1), 124-141. http://ijlls.org/index.php/ijlls

Tohol Simamora, Edi Harapan \& Nila Kesumawati. (2020). Faktor-faktor Determinan Yang Mempengaruhi Prestasi Belajar Siswa. Jurnal Manajemen, Kepemimpinan, dan Supervisi Pendidikan, 5(2), 191-205. https://www.researchgate.net/publication/341545692_FAKTORFAKTOR_DETERMINAN_YANG_MEMPENGARUHI_PRESTASI_BELAJAR_SISWA

V. S. Mullis, M. O. Martin, P. Foy, A. Arora. (2012). TIMSS 2011 International Results In Mathematics. Chesnut HIll: TIMSS \& PIRLS International Study Center, Boston College. 
Malaysian Journal of Social Sciences and Humanities (MJSSH), Volume 6, Issue 12, (page 137 - 157), 2021

DOI: https://doi.org/10.47405/mjssh.v6i12.1210

Yung-hsun Cheng \& Chia-wen Weng. (2017). Factors influence the digital media teaching of primary school teachers in a flipped class: A Taiwan case study. South African Journal of Education, 37(1), 1-12. doi: 10.15700/saje.v37n1a1293 